\title{
The Impact of Electronic Management on the Employees' Performance Field Study on the Public Organizations and Governance in Jerash Governorate
}

\author{
Khaled Adnan Bataineh ${ }^{1}$ \\ ${ }^{1}$ Department of Business Administration, Faculty of Administrative Science and Finance, Irbid National University, \\ Jordan
}

Correspondence: Dr. Khaled Adnan Bataineh, Department of Business Administration, Faculty of Administrative Science and Finance, Irbid National University, Jordan.

Received: October 18, 2017

Accepted: November 26, 2017

Online Published: November 28, 2017

doi:10.5430/jms.v8n5p86

URL: https://doi.org/10.5430/jms.v8n5p86

\begin{abstract}
The study aimed at knowing the impact of Electronic management on the employees' performance- a field study that was applied on the public organization in Jerash Governorate, the researcher followed the descriptive analytical approach, then analyze the relationship between the independent variable (Electronic management) and the dependent variable (employees' performance), aiming at knowing the impact of the independent variable on the dependent variable. In order to achieve the study goal, a 24 paragraphs questionnaire was developed to gather the initial information from the study population, and then analyze these information using SPSS V 22. The study found that the requirements of Electronic management are available in the public governance in Jerash, and the results showed a significant positive relationship between all dimensions of Electronic management and employees' performance. The study provided a group of recommendations to speed up adopting the electronic management in the public governance in Jordan specially in Jerash; one of the most important recommendations was the continuous follow up on applying the concepts of Electronic management in the different public, private, and service governance in order to keep up with the challenges and development and focus on accessibility and globalization and providing the possible services, within a comprehensive functional model to satisfy the widest slice of the community as soon as possible and in the least cost possible.
\end{abstract}

Keywords: electronic management, hardware and software, databases, business networks, information systems and technology experts, employees' performance, public governance in Jerash

\section{Introduction}

The human communities are living the information age now due to the revolution of information technology and knowledge burst because of the modern communication networks. It is the world of knowledge and information technology now, and what we see now of practical and scientific achievements in the different aspects of life have one main cause in common which is the availability of information and its technical methods that helped eliminate the time and place barriers allowing innovation towards better future (BelQasem: 2014). The information transformation in light of the economical, political, social, and technical variables participated in achieving a basic and qualitative change in the environment of the public and private business institutes as a vital instrument and one of the institutes' resources to achieve the strategic and relative competitive advantage, develop the institutes, enhance the quality of work, and implement the work strategies and operation management efficiently in the various activities practiced by the institutes on the ground (AlTaei: 2009, AbuAloush: 2015).

The efficiency of the management depends on the quality of the managerial decisions it makes which has great importance compared to other managerial practices, and it is considered the backbone of the management, that's why the correct information is needed to help the management in making the decisions in the right form and time to deal with the work challenges and its consequences, and accelerate the procedures and facilitate accessing the services provided by the management, so the costumer care won't be an unavoidable evil (Badreddin:2015, Irtaimeh et al,.: 2016). The $21^{\text {st }}$ century witnessed huge steps in the increasing use of the different technological instruments including the modern technologies of information and communication, this digital and information revolution 
represents a chance for the small and medium organizations to make a large step toward developing its innovative and creative potential and integrate into the international virtual economy, applying the instruments of this modern technology is necessary to make the best use of its efficiency and processing speed to give the desired results in a short time without the mistakes done by the human in his changing and unstable environment (AlKhawaldeh and AlHunaiti,:2008) (Sommer And James: 2004 sabualoush et al.,:2017). Due to all that, the organization considers information technology and organizing the information as a necessary requirement to overcome the increasing challenges faced, and avoid the recession that could lead to losing some of the market share if it didn't keep up with the new developments in the different fields. It became common and usual to do many applications in the different functions of the organization (productive, marketing, commercial and others like; budgeting, following the receiving and paying accounts, users management, stock management, production planning,...etc) using computers in a short period of time, so organization management doesn't depend on intuition and prediction, but depends on scientific methods. This intervention will list some software and will also focus on the the problems facing the users of these software especially the needed database which the user can't obtain, and will try to focus on some of these software that is rich in its content and illustrate how to use it in the applied aspect in the decision making process in the small and medium organizations (BelQasem: 2014).

\subsection{Problem of the Study}

Public organizations and governance are facing many challenges related to improving their performance, quick completion of papers, and administrative flabbiness, this resulted in long waiting hours for the people in order to finish their work what cost them more time, effort, and money. This require the public governance to improve their performance achieving the efficiency within an environment that is marked with advanced information technologies and systems, and it is imperative for them in light of this technological development to change from the handy traditional transactions into the electronic ones; which gives short execution time and more accuracy in addition to raising the employees' performance, minimize the administrative mistakes, and reduce the bureaucratic and administrative levels needed to complete the transaction. According to all that, the problem of the study is mainly about the role of the electronic management in improving the general role of the public sector employees in view of the strategic role played by the information in forming the administrative decisions and managing the operations in the different activities of the public governance in general and specially the governance in Jerash, in addition to the current challenges like privatization, administrative reform for the Jordanian public departments, and the inflation in the public administrative departments and the increase in their tasks and responsibilities. In light of all the above, the problem of the study can be summarized in the following questions:

- What are the projections of the public department employees in Jerash regarding the importance of the electronic management?

- What are the projections of the public department employees in Jerash regarding the importance of the electronic management in improving their employees' performance?

\subsection{Importance of the Study}

- Provide a theoretical framework that links the electronic management and employees performance in the public departments in Jerash.

- It deals with a subject that is very important in the public departments in Jerash which is the role of the electronic management in improving the employees' performance in light of the current technological developments as most of the countries went a long way in electronic transactions and some countries started providing all services electronically.

- The importance of the public departments in Jordan in facilitating the work for the citizens and providing services in the least time possible and the most accurate way what saves time and effort.

\subsection{Goals of the Study}

- Studying the impact of hardware and software on improving the performance of the employees in the public departments in Jerash.

- Studying the impact of networks on improving the performance of the employees in the public departments in Jerash.

- Studying the impact of databases on improving the performance of the employees in the public departments in Jerash. 
- Provide suggestions and recommendations based on the rests of the study that helps shifting toward electronic management in providing services for the citizens in the public departments in Jerash.

\subsection{Model and Hypotheses of the Study}

The study is built on a group of hypotheses formed according to the problem of the study, the main hypothesis is:

- There are no significant impact for the electronic management (hardware, software, business networks, databases, and human resources specialized in information technology) a level $(\alpha \leq 0.05)$ on the employees' performance in the public departments in Jerash. Out of this hypothesis, many sub hypotheses were derived;

- There are no significant impact for hardware and software at level $(\alpha \leq 0.05)$ on the performance of the employees in the public departments in Jerash.

- There are no significant impact for the databases at level $(\alpha \leq 0.05)$ on the performance of the employees in the public departments in Jerash.

○ There are no significant impact for business networks at level $(\alpha \leq 0.05)$ on the performance of the employees in the public departments in Jerash.

- There are no significant impact for the experts in information technology at level $(\alpha \leq 0.05)$ on the performance of the employees in the public departments in Jerash.

Dependent and independent variables
Independent variables
Dependent variables
Electronic management
Employees' performance

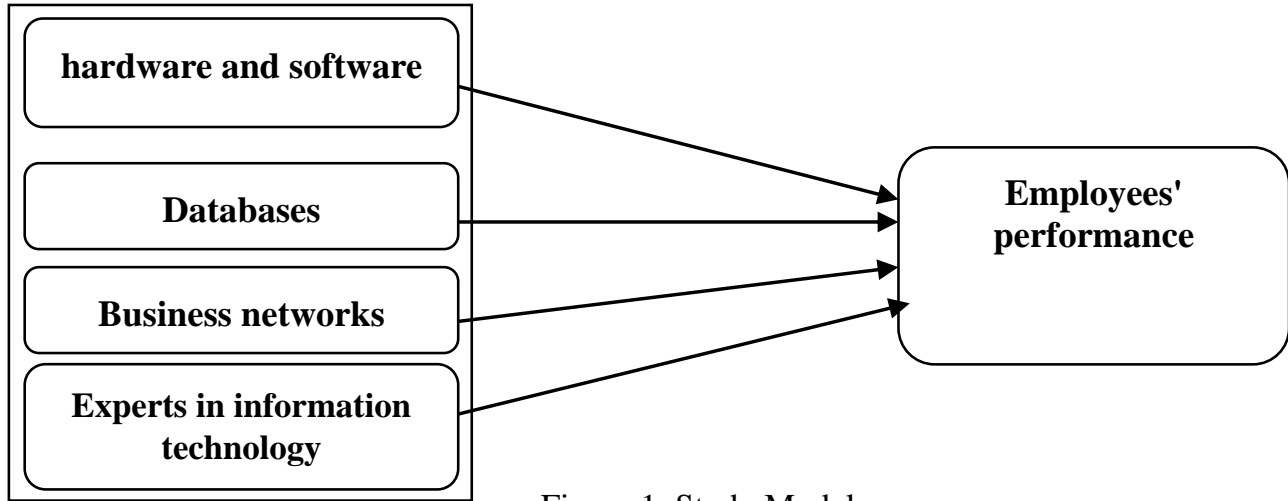

Figure 1. Study Model

Made by the researcher based on the studies (AlRasasi: 2016, Al Abdullah: 2006, Rawash 2014, Sultana et. al., 2012, Iqbal, 2015)

\subsection{Previous Studies}

The study of AlAwamleh (2003) the issue of the electronic management aiming at providing a comprehensive theoretical analysis for the quality of the electronic government and administration and survey the trends of a sample of employees from public and private sectors in Jordan in order to know their trends regarding the aspects of the electronic management. The study used the descriptive analytical approach and the researcher used a questionnaire to collect the information. The sampe of the study was 700 employees in 20 different public and private institutions. After distributing the questionnaires to all the sample members, 581 questionnaires were returned (the ratio was $83 \%)$. The results showed that $(62 \%)$ of the institutions use the computers widely in their work, and $(67 \%)$ of the institutions use electronic or digital techniques in their activities. The failure of the legislations came in the first place among the obstacles of the electronic management with an average of (4.1). the study recommended that shifting toward electronic government should be done gradually with careful and studied steps, in addition to providing the needed human, financial, technological, information, and legislation requirements before shifting toward electronic 
government.

In a study done by Al Abdullah (2006) about the electronic government and its impact on the efficiency of the operations by studying the efficiency of the executed operations in aspects of information and services in light of the electronic government in Saudi Arabia. The study consisted of two parts: the first one dealt with the theoretical framework by studying the concept of electronic government, its requirements, elements, benefits, and obstacles on its application. The second part was in the field, and it depended on the descriptive analytical approach and the case study approach and included the public employee and the beneficiary. The researcher selected 400 sample members randomly from Riyadh, Jeddah, Abha, and AlDammam, the returned questionnaires were 299 with a ratio of $78 \%$, out of which 110 questionnaires were from employees without mentioning their nationality and 189 from Saudi employees. The study found that applying the electronic government will increase the efficiency of the operations and unify the procedures, in addition it goes with the customs and traditions and the religious and social values. The low social awareness of the sample members was one of the obstacles that face the application of the electronic government with a ration of $73 \%$. The study recommended putting precise procedures and train the employees on the information sector to insure executing the operations in the electronic government.

The study of AlUteibi (2007) the impact of applying the electronic government on the employees of King AbdulAziz university. The study aimed at identifying the relationship between the level of employees performance and a group of independent variables like; economical, administrative, social, technical, and security. The researcher used the associative descriptive approach, she distributed 1589 questionnaires and 393 were returned with a ratio of (24.7\%). The study found many results and the most important ones were: there is a positive relationship between the impacts of applying the electronic government and the level of employees' performance, and the administration of the university provides the employees with the needed computers to support applying the system of electronic government. The study recommended holding lectures and workshops for the university employees to prepare them to use electronic government system, and to provide the suitable financial support for the training workshops. This study is one of the important applied studies that dealt with electronic government and its impacts on the employees in one of the Saudi universities.

The study by AlHadi (2006) is one of the most important theoretical studies that dealt with electronic government as a tool for administrative reform, it clarified the concept and goals of the electronic government. The researcher discussed the model of the electronic government and how it provides the services electronically, he also highlighted the needed skills to activate the electronic government like: information and knowledge management, technical skills, communication and presentation skills, and electronic government project management. Then the study discussed the elements of the successful shifting toward electronic government including the administrative reform and providing an administrative leadership, cooperation with the society, and the participation of the people and the community based organizations in the decision making process regarding the electronic government. The study also clarified the stages of the development of the electronic government. The researcher concluded with a group of recommendations that help the governments in the successful execution of the electronic government systems including; provide the basic environment through providing and efficient communication systems, bridge the digital gap to reach to the information, keep the privacy of the information, provide a flexible system for electronic records management.

The study of AlRasasi (2016) which was titled "the impact of applying the electronic management on achieving the knowledge management in the Jordanian banks". The study aimed at knowing the impact of applying the electronic management on achieving the knowledge management in the banks, and it was an applied study. In order to achieve the goals of the study, the descriptive analytical approach was used, then the relation between the independent variable (electronic management) and the dependent variable (knowledge management) was analyzed. The results showed that there is a significant impact for applying the electronic management on knowledge management. The study presented some recommendations including introducing the operations of the electronic management on several dimension like, improving the performance and the level and quality of the administrative services.

The study by Abu Ashour and AlNemri (2013), titled "the level of applying electronic management in Yarmouk University from the perspectives of the board members and administrators". This study aimed at exploring the level of applying the electronic management in Yarmouk university, the population was all the educational and administration board members who were (2140), the sample was (647) out of which 320 educational board members randomly selected from the educational board pool, and 327 administrators randomly selected from the administration pool. In order to achieve the goals of this study, a 55 paragraphs, 4 dimention questionnaire was developed. After applying the tool, the results showed the application of the electronic management was high from the perspective of the educational board members, and there were no differences in their perspectives regarding the 
level of application in Yarmouk University attributed to the difference in the study variables, academic rank, gender, or faculty on the instrument and in al dimension. The results also showed that there were no differences in the perspectives of the administrators regarding the level of application attributed to the gender variable, and there were differences attributed to the qualification in the diploma holders and below, bachelor holders and higher education, in the dimention of electronic planning and electronic control and evaluation, in favor of the bachelor holders. There were differences between Diploma holders and higher education bearers in favor of higher education in the electronic execution axis.

The study " An Investigation for Electronic-Management Use in Educational Projects Management (A Case Study in AL Baha- KSA Area), by Shakkah and AlGamdi (2015) aimed at the possibility of shifting toward electronic management in educational project management in AlBaha area, it used the descriptive analytical approach. The study population was 74 employee and engineer, out of which 13 were administration unit managers, 18 heads of division, 9 administrators, 22 engineering consultants, and 36 engineers from the contractors who did educational projects in AlBaha area. All of them agreed on the importance of the electronic management, with it, in addition to the automation of the transactions, the reports will be available immediately, the transactions between the different levels of the consultants will be easier, and it will reduces the time and effort and increase the accuracy. The study shows the need of shifting toward electronic management, and overcome the obstacles that prevent it. This study recommended launching a strategic plan for the educational projects management in AlBaha area, and this requires the support from the higher administration, the availability of the financial support, provide the internet services to all projects sites, prepare trainings and workshops, and hold meetings to raise the awareness among the employees regarding the electronic management.

\section{Theoretical Background}

\subsection{Electronic Management}

The international changes, especially the digital revolution, demanded more pressure on the public sector where there is a persistent need for updating the electronic management in a way reflected on the citizens and on all the public institutions in the form of more efficient service providing, in addition to the best use of the government's information resources where it is available for everybody which will raise the level of achievement and enhance the competitive abilities within the electronic government, thus, the electronic government will be one of the main pillars to transform the community to an information community (Awamleh, 2002). AlMajdoub (2005) thinks that what increases the need for the electronic applications is the situation of the public services as a complicated situation, so we need a new managerial matrix that move us to a more flexible situation. While AlBakhar (2006) clarified that adding the word "electronic" to the management is an indication for the government's intention to accelerate the procedures and facilitate the reach for the services. Undoubtedly, realizing the dream of the electronic management requires the creation of a valuable infrastructure, linked to what trends and values the people have concerning the concept of the government and its relation to the employees. The steps that we can start with is replacing the paper communication with all its routine and time waste with an electronic method and provide a database and information network between the different governance and ministries who have a direct contact with the services and needs of the citizens. Yaseen defined the electronic management as practicing the different types of work and procedures using the modern electronic techniques and instruments, because the electronic management is one of the modern systems that aim at enhancing the execution of operations using the communication networks (Yaseen, 2010). In addition to that, it is one of the administrative tools based on the high capacity of the internet and the business networks through the administrative tasks like planning, guidance, and monitoring the internal resources of the company in order to achieve a group of goals (Aboud, 2004). AlA'ani and Jawad, defined it as using the information technology systems and business networks to enhance the production process and increase the capacity of the organization (AlA'ani and Jawad, 2014). AlAjez defined it as a modern process where the management employs complete electronic systems based on information technology to enhance the administrative operations inside the organization by transforming it from the handy form to digitally run business, which saves effort and time and achieves the maximum benefit of the available information (AlAjez, 2011).

\subsection{Importance of Electronic Management}

The availability of modern information systems participates efficiently in achieving the goals and strategies of the organizations globalization and fulfilling the desires of the organization in order to continue and stay up to date. This trend insures the following indicators: (Qandeel, 2004) (Abu Ashour and AlNemri, 2013)

- Information systems and technologies are considered an effective instrument to reduce the cost of the production elements. 
- $\quad$ Participate in the innovation to create new opportunities in putting up new products.

- $\quad$ Improve the customer services by fulfilling the needs in the least time possible.

- $\quad$ Reduce the time and the effort needed to finish the procedures due to the ease of retrieving the information.

It also helps revealing the deviations sooner to prevent its aggravation and put the needed treatment. In the same time, Khammas (2002) assured the importance of information management in the last three decades where it became the motive to enhance its presence in all commercial and services public institutions, due to the role it plays when applied, and this gave it extra advantages. AlWadi and AlWadi (2011) indicated the importance of the technical and scientific progress, and the continuous push to raise the quality of the outcomes and assure the safety of the procedures, where the time factor is the main competitive aspects between organizations and it is not accepted to delay the execution of operations, and that is because the opportunities are linked to the time element, thus, the importance of the electronic management is in:

- The ability to deal with huge amounts of information.

- $\quad$ The ability to deal with great numbers of users and beneficiaries.

- $\quad$ Facing the increase of information and controlling it.

- The necessity of continuous communication among employees within the work domain.

- $\quad$ The trend toward using the technical progress and depending on information in decision making.

\subsection{The Determinants of Electronic Management}

It is known that the main obstacle facing the actual application of the electronic management is the traditional way of working in the public governance, which doesn't prefer the administrative changes. The decision makers in the public sector refuse changing the standards and principles of the administrative work in their institutions in a way that facilitate the application of electronic management. AlTaei (2007) referred the domain of determinants to main dimension linked to a group of limitations and the weakness points of achieving the electronic management including:

- Economical axis: the shortage of the budget, the poor investment infrastructure and administrative corruption.

- Technical axis: includes the lack of specialized skills in technology and communication, high cost for using the Internet, and the lack of special information standards.

\subsection{The Requirements of Applying Electronic Management}

Adopting the electronic management by the organizations became a main standard for their ability to compete and succeed in light of the challenges they face, and due to the main role of those techniques in having these advantages. Due to all that, it became a must to accredit a group of policies that considered main factors to assure the safety for the best use of information technologies and systems as listed by (Ruth, 206):

- The commitment of the higher administration to adopt this technology and stick to the standards.

- $\quad$ Provide the infrastructure needed for this technology.

- $\quad$ Provide all the main needs and participate effectively in the work.

- Provide the needed technical and theoretical frames (qualitative and quantitative) as a tool to provide the financial and moral incentives for the individuals.

- Widen the use of computers in the work.

\subsection{Elements of Electronic Management (Dimension of Electronic Management)}

\subsubsection{Hardware and Software}

- The hardware is computers and their accessories, so it is a group of linked devices, doing certain jobs, and these jobs are harmonically linked to the software to form the computer system (Al Husseineh, 2011). While the software is a group of instructions given to the computer to perform certain tasks, and they are very important because it allows all parts of the computer to work together (Leonard and Valacich, 2006), they are also known $\mathrm{s}$ a group of instructions and demands perceived by the computer, and help guiding it to perform a certain task, and they are the systems and programs that run the devices including the data, information, and knowledge and they define the processes to be done by the devices, and include:

- $\quad$ Operating software: which run the computer and make it capable of performing the tasks. 
- Application software: the written systems for special applications that process the organization data in the different tasks by the end user (AlSabbagh: 1996, Leonard and Valacich:2006).

\subsubsection{Database}

Many definitions of data base were listed, most of them defined it as a group of data linked together in logical relationships (Elmasri and Shamkant: 2004), database are also considered as a system to manage a file that include all the data from the organization and provide modern techniques to reach them (Whitely, 2004, abualoush:2015) . (AlHumaidi et. al. 2004) provided a more comprehensive definition of the database as a group of data stored in the computer to fulfill the needs of the users in an easy and efficient way and are circulated within the organization's different activities. According to all these definitions of databases, that resulted from the big problems faced by the organizations at all levels where they used the traditional information saving methods (on papers), so the databases came to end this traditional methods and solve the problems of the traditional files like repetition and confliction, difficulty of access, in addition to safety and security issues and the no synchronized access (Silberschatz et. al., 2006).

\subsubsection{Networks}

A group of computers and attaced devices linked with a communication channel with the ability to exchange information and other resources (Leonard and Valicech: 2006), it is considered the backbone of the organizations' work in the new era when the information are increasing and the need to exchange information between individuals and organizations is rising, and this is considered a great advantage of networks, in addition to sharing the software and systems among users, sharing the hardware attached to the network like the printers, exchanging the files easily, safely and quickly, and provide a discussion board for the users regardless the distances, in addition to providing distributed processing (AlHusseini and Dawood, 2006).

\subsubsection{Experts in Information Technology and Information Systems}

The individuals who develop and operate the information systems including the designers and analysts of these systems, programmers, database managers, network managers, and the information system managers (Louden and Louden, 2012).

\section{Employees' Performance}

Employees' performance is one of the most studies variables with the impact of the independent variables on it in the administrative sciences, because it plays an important role in the performance of the organizations, and is considered the launching point towards the success and sustainability of the organization (Vratskikh et. al., 2016). Employees' performance is the efficiency and effectiveness of the employees daily duties in order to meet the expectations of the customers, and performance is the effectiveness of the employees' procedures that help achieving the goals, effectiveness and efficiency are two of the vital elements of the employees' performance (Sultana et. al., 2012, Iqbal, 2015). Or it is the level of employees' implementation of their of their skills, knowledge, and bearings or their trends toward achieving the desired results and the expected goals (Okoth, 2014). Performace depends on a mix of ability and effort, acquired opportunities, it is the sum of behavior and its results, the ability of the one to achieve the results by the submitted effort in certain circumstances. Thus, performance is the result of the relation between; effort, ability, tasks, and acquired opportunities, and it is the quality and quantity of the work results achieved by the employee while fulfilling his tasks according to his responsibilities (Maharani et al., 2013، Razi :2017، Gungor:2011).

Employees' performance is defined as behavioral responses reflecting what the employee learned or trained on, and is the result of the mental, psychological, and is the interaction of the employee's behavior, and this behavior is determined by the interaction of the employee's effort and abilities in the organization (AlSaawi, 2014). Performance is defined as the record of the results gained in a job or wwork activity during a specific period of time (Razi, 2017). Performance is an expression of the information to evaluate the success of the work in achieving the goals (Darsana, 2014), the organization always has a bigger chance to develop and grow when the performance of its employees is more efficient and with higher quality (Razi, 2017). Employees' performance can be measured using many indicators including quality, and it can be measured using a percentage of what the employee accomplished of his tasks, or the accuracy of the work he did compared to other work. One of the indicators is the satisfaction of the customers, where it can be measured by the number of customers who are loyal to the organization or by the customers' suggestions and complaints (feedback). It also can be measured using timelines, by calculating the speed of completion of a job or when giving the employee a specific task, also the ratio of presence and absence, in addition to that it can be measured by the ratio of achieving the goals innovatively (Njanja, 2013). 


\section{Methodology of the Study}

The field descriptive and analytical approach was used, where a questionnaire was designed to collect the information and analyze them in order to test the study hypotheses, and embody its sophisticated goals to know the impact of electronic management on the employees' performance in the public governance, Thus, the public organizations' need for modern and flexible technology to replace the handy work and keep it in direct contact with the customers to fulfill his needs and listen to his suggestions became a necessity in light of the diverse alternatives he has due to the international openness. The diversity of the information systems' pillars in the different activities eases the link of all operations especially when related to modern technologies which are based on quick information exchange in the least time in all circumstances. In addition to the previous level, the organization depends on the information technology in the decision making, like the production process which requires modern devices and technologies to control the products, or what is known as the "Computer Based Production", so the device can replace the worker even in the routine work, thus we can see that the available level of technology is taken into consideration when making the decision regarding its course like; increasing the capacity or adding new designs to the product, because it is all related to this technology. Its impact is also obvious on other levels like storing, the organization always needs an automated system to control the stock and make sure it doesn't face any shortage of the main material for the production and other different aspects in the organization.

\subsection{Population of the Study}

The study included all the public governance in Jerash (16 departments), while the employees included were as follows:

Table 1. Study population and sample in the public governance in Jerash

\begin{tabular}{lll}
\hline Job Level & Number & Percentage \\
\hline Managers & 16 & $85 \%$ \\
\hline Heads of divisions & 22 & $100 \%$ \\
\hline Employees & 58 & $50 \%$ \\
\hline Total & 96 & $100 \%$ \\
\hline
\end{tabular}

In light of the previous table that clarifies the study population and sample, the managers were 16 with a ratio of $85 \%$, 22 heads of divisions with a ratio of $100 \%$, while the 58 employees were only $50 \%$ due to the high number of employees in the public goveranc in Jerash.

\subsection{Study Tools and Sources of Information}

In order to achieve the main goal of the study which is measuring the impact of electronic management on improving the performance of the employees, the following tools were used to collect the information including secondary sources, where multiple sources were used like books, references, periodicals, and previous studies. While regarding the primary sources, the questionnaire was the main tool to collect the information concerning the independent variabl (electronic management) with all its dimension ; hardware and software, databases, business networks, and experts in information technology, and the dependent variable (employees' performance). The questionnaire was developed according to the administrative literature related to the subject of the study, and the study used five-point Likert scale responses ranging from $\quad(1=$ strongly agree, $2=$ agree, $3=$ neutral, $4=$ disagree , $5=$ strongly disagree $)$, and SPSS V. 22 was used.

The questionnaire contained three main parts, where the first one included the demographic information (gender, job level, qualification, and job position), the second part included the paragraphs that measure the dimension of the independent variable of electronic management which were four main dimension (hardware and software, business networks, databases, and experts in information systems and technology) and was designed depending on the study of (Alrasasi: 2016) and the study of (Rawash: 2014) and was measured in paragraphs 1-16. Finally, the third part included the dependent variable (Employees' performance) and was measured in paragraphs 17-24, and was designed according to the study of (Al-Buhussin and El-garaihy).

\subsection{Validity and Reliability}

The questionnaire was arbitrated by a group of specialized experts who have experience in designing the 
administrative sciences questionnaires, it was presented to members of the educational board in Irbid National University in the departments of information systems and business administration. In addition, it was presented to a group of managers and experts in information technology and information systems who have wide experience in order to validate the paragraphs of the questionnaire. After that, their suggestions and recommendations regarding the paragraphs were considered, and the questionnaire was amended prior to the distribution.

\subsection{Stability of the Study Tool}

The reliability coefficient was derived using the Cronbach's Alpha for all the variables in all dimension, which are the electronic management as the independent variable in all its dimension (hardware and software, databases, business networks, experts in information technology), and the employees' performance as the dependent variable, Cronbach's alpha reliability coefficient normally ranges between 0.0 and +1.0 . The closer Cronbach's alpha is to 1 , the higher the internal consistency reliability. However, the minimum of Cronbach's alpha coefficient is 0.6 (Hair et al., 1998). The values of the reliability coefficient were acceptable between (0.78- 0.91), "This is evidence that the internal consistency reliability was very good", as illustrated in table (2)

Table 2. The internal consistency (Cronbach's Alpha) for all the variables

\begin{tabular}{lll}
\hline Variable & Dimention & Cronbach's Alpha \\
\hline \multirow{4}{*}{ Electronic management } & Hardware and software & 0.86 \\
\cline { 2 - 3 } & Databases & 0.78 \\
\cline { 2 - 3 } & Business networks & 0.90 \\
\cline { 2 - 3 } & Experts in information technology & 0.86 \\
\hline Employees' performance & Employees' performance & 0.89 \\
\hline
\end{tabular}

\subsection{Statistical Methods Used}

The Statistical Package for the Social Sciences (SPSS V. 22) was used to process the data collected using the questionnaire and the following statistical procedures were also used, Descriptive statistics: in order to describe the sample, the frequencies and percentages were used, and the mean and standard deviations were calculated to measure the dispersion of the answers from the average and determine the importance level., Linear regression to test the validity of the model and the impact of the dependent variable, in addition to analyzing the variance to calculated F-value and clarify the impact of the independent variable on the dependent variable.

\subsection{Demographic Characteristics of the Sample Members}

After analyzing the characteristics of the sample members it turned out that most of the managers are BSC holders (12) which makes 75\%, and 4 are masters holders (25\%). 25 heads of divisions were BSC holders (78\%), 2 masters holders (6\%), and 5 diploma holders (16\%). 28 employees were BSC holders (58\%), and 20 diploma holders (42\%).

Regarding the experience, most of the managers (11) have 9 or more years of experience (69\%). 24 heads of divisions have (6-9) years of experience (75\%). And for the employees, the majority (32) have (6-9) years of experience $(67 \%)$.

\subsection{Descriptive Statistics}

Table 3. The Descriptive statistics of the study variables

\begin{tabular}{llll} 
Study Variables & mean & Standard deviation & Level \\
\hline E- management & 3.77 & 0.845 & High \\
\hline Hardware and softwar & 3.77 & 0.81 & High \\
\hline Databases & 3.76 & 0.86 & High \\
\hline Business networks & 3.88 & 0.82 & High \\
\hline Experts in information technology & 3.70 & 0.89 & High \\
\hline Employees' performance & 3.81 & 0.91 & High \\
\hline
\end{tabular}

Table 3 indicates that the mean and the standard deviation for all dimension of the electronic management was high with a total average of (3.77) in the public governance in Jerash, where the business networks came first with an average of (3.88), followed by the equipment and software with an mean of (3.77), databases came third with an 
average of (3.76), while the last place was for the information technology experts with an average of (3.70). For the dependent variable (employees' performance) the averages and standard deviations were high with a total average of (3.81) for all its paragraphs.

\subsection{Testing the Study Hypotheses}

To assess the study hypotheses, the multiple regression analysis was applied. The results of the study hypotheses are displayed below.

The main hypothesis "there is no statistically significant impact for the electronic management (hardware and software, business networks, databases, and information technology experts) at level ( $\alpha \leq 0.05)$ on the employees' performance in the public governance in Jerash".

Table 4. Regression analysis test

\begin{tabular}{|c|c|c|c|c|c|c|c|c|}
\hline \multirow{2}{*}{$\begin{array}{l}\text { Dependent } \\
\text { variable }\end{array}$} & \multirow[b]{2}{*}{$\mathrm{R}$} & \multirow[b]{2}{*}{$\mathrm{R}^{2}$} & \multirow[b]{2}{*}{ F value } & \multirow[b]{2}{*}{ Sig } & \multicolumn{4}{|l|}{ Coefficient ( a) } \\
\hline & & & & & $\begin{array}{l}\text { Independent } \\
\text { variable }\end{array}$ & $\beta$ & $\begin{array}{l}\text { Calculate } \\
\text { d T }\end{array}$ & Sig* \\
\hline \multirow{4}{*}{$\begin{array}{l}\text { Employees' } \\
\text { performance }\end{array}$} & \multirow{4}{*}{0.429} & \multirow{4}{*}{0.479} & \multirow{4}{*}{42.958} & \multirow{4}{*}{0.000} & $\begin{array}{l}\text { Hardware and } \\
\text { software }\end{array}$ & 0.487 & 5.534 & 0.001 \\
\hline & & & & & Databases & 0.244 & 5.544 & 0.005 \\
\hline & & & & & Business networks & 0.473 & 3.567 & 0.000 \\
\hline & & & & & $\begin{array}{l}\text { Information } \\
\text { technology experts }\end{array}$ & 0.457 & 6.689 & 0.000 \\
\hline
\end{tabular}

The results from the previous table show that the impact of the independent variable (electronic management) on the dependent variable (employees' performance) is statistically significant, where the calculated $\mathrm{F}$ value was (42.958), with Sig. $F=0.000$ which is less than 0.05 . The correlation coefficient was $(\mathrm{R}=0.429)$ indicates a positive relationship between the two variables, and the determination coefficient was $\left(R^{2}=0.479\right)$ indicates that $47.9 \%$ of the variance in the employees performance can be explained by the variance in the electronic management.

Table (4) also shows that the dimension of the electronic management (hardware and software, databases, business networks, information technology experts) have an impact on improving the employees' performance in the public governance in Jerash, where $\mathrm{T}$ was $(5.534,5.544,3.567,6.689)$, with P- values $(0.000,0.005,0.000,0.000)$ which are les than the significance level $\alpha \leq 0.05$. And according to the values of $\beta$, the hardware and software came first in the power of impact where the $\beta$ value was $(0.489)$, followed by the business networks $(\beta=0.473)$, information technology experts came third $(\beta=0.457)$, and finally the databases was in the fourth place $(\beta=0.2444)$. Thus, we acc the main hypothesis and accept the alternative hypothesis that says there is a significant impact for the electronic management (hardware and software, business networks, databases, and information technology experts) at level $\alpha \leq$ 0.05 on the employees' performance in the public governancen Jerash.

Table number (4) shows that there is a significant impact for the electronic management (hardware and software, business networks, databases, and information technology experts) at level $\alpha \leq 0.05$ on the employees' performance in the public governance in Jerash.

Table 5. The results of the linear regression for the impact of the electronic management (hardware and software) on the employees' performance in the public governance in Jerash

\begin{tabular}{|c|c|c|c|c|c|c|c|c|}
\hline \multirow{2}{*}{$\begin{array}{l}\text { Dependent } \\
\text { variable }\end{array}$} & \multirow[b]{2}{*}{$\mathrm{R}$} & \multirow[b]{2}{*}{$\mathrm{R}^{2}$} & \multirow[b]{2}{*}{$\begin{array}{l}\mathrm{F} \\
\text { value }\end{array}$} & \multirow[b]{2}{*}{ Sig } & \multicolumn{4}{|l|}{ Coefficient ( a) } \\
\hline & & & & & $\begin{array}{l}\text { Item Independent } \\
\text { variable }\end{array}$ & Beta & $\mathrm{t}$ & Sig.(P-value) \\
\hline $\begin{array}{l}\text { Employees' } \\
\text { performance }\end{array}$ & 0.453 & 0.534 & 40.43 & 0.000 & $\begin{array}{l}\text { Hardware } \\
\text { software }\end{array}$ & 0.443 & 3.567 & 0.002 \\
\hline
\end{tabular}

The results in the previous table show that the impact of the independent variable (electronic management) in the axis of hardware and software on the dependent variable (employees' performance) is statistically significant, where 
the calculated $\mathrm{F}$ was (40.43) with significance level ( $\operatorname{sig} \mathrm{F}=0.000$ ) which is less than 0.05 , and the correlation coefficient $(\mathrm{R}=0.524)$ indicates a positive relationship between the two variables. The determination coefficient was $\left(\mathrm{R}^{2}=0.534\right)$ indicates that $53.4 \%$ of the variance in the employees' performance can be explained by the variance in the hardware and software.

Table number 5 shows that $(\beta=0.534)$ which indicates the direct impact of the hardware and software in improving the employees' performance in the public goverance in Jerash, where t was (3.567) with a P-value of (0.001) which is less than the significance level of $\alpha \leq 0.05$, thus, we reject the first sub hypothesis and accept the alternative hypothesis that says there is a significant impact for the hardware and software, at $\alpha \leq 0.05$, on the employees' performance in the public governance in Jerash.

Table 6. the results of the linear regression for the impact of electronic management (databases) on the employees' performance in the public governance in Jerash

\begin{tabular}{|c|c|c|c|c|c|c|c|c|c|}
\hline \multirow[b]{2}{*}{$\begin{array}{l}\text { Depended } \\
\text { variable }\end{array}$} & \multirow[b]{2}{*}{$\mathrm{R}$} & \multirow[b]{2}{*}{$\mathrm{R}^{2}$} & \multirow[b]{2}{*}{$\mathrm{F}$ value } & \multirow[b]{2}{*}{ Sig } & \multicolumn{5}{|c|}{ Coefficient ( a) } \\
\hline & & & & & $\begin{array}{l}\text { Independent } \\
\text { variable }\end{array}$ & & Beta & $\mathrm{T}$ & $\begin{array}{l}\text { Sig.(P-valu } \\
\text { e) }\end{array}$ \\
\hline $\begin{array}{l}\text { Employees' } \\
\text { performance }\end{array}$ & 0.242 & 0.221 & 25.455 & 0.000 & $\begin{array}{l}\text { Hardware } \\
\text { software }\end{array}$ & and & 0.326 & 4.554 & 0.000 \\
\hline
\end{tabular}

The results in the previous table show that the impact of the independent variable (electronic management) in its databases axis on the employees' performance is statistically significant, where the calculated $\mathrm{F}$ value was (25.455), with a significance level of ( $\mathrm{Sig} F=0.000)$ which is less than 0.05 . the correlation coefficient $(\mathrm{R}=0.242)$ indicates a positive relationship between the two factors, and the determination coefficient $\left(\mathrm{R}^{2}=0.221\right)$ indicates that $22.1 \%$ of the variance in employees' performance can be explained with the variance in the databases. The table also shows that $(\beta=0.326)$ and this indicates the direct impact of the databases on improving the employees' performance in the public governance in Jerash, where t was (4.445) with a P-value of (0.001) which is less than $\alpha \leq 0.05$. Thus, we reject the second sub hypothesis and accept the alternative hypothesis that says there is a significant impact at level $\alpha \leq 0.05$ for the databases on the employees' performance in the public governance in Jerash.

Table 7. The results of the linear regression analysis for the impact of electronic management (business networks) on the employees' performance in the public goverance in Jerash

\begin{tabular}{lllllllll}
\hline & & & & & \multicolumn{2}{l}{ Regression coefficient } \\
\cline { 5 - 7 } $\begin{array}{l}\text { Depended } \\
\text { variable }\end{array}$ & $\mathrm{R}$ & $\mathrm{R}^{2}$ & F value & $\mathrm{Sig}$ & $\begin{array}{l}\text { Item } \\
\text { Independent } \\
\text { variable }\end{array}$ & Beta & $\mathrm{t}$ & Sig.(P-value) \\
\hline $\begin{array}{l}\text { Employees' } \\
\text { performance }\end{array}$ & 0.473 & 0.478 & 30.498 & 0.000 & $\begin{array}{l}\text { Business } \\
\text { networks }\end{array}$ & 0.379 & 6.897 & 0.000 \\
\hline
\end{tabular}

The results in the previous table show that the impact of the independent variable (electronic management) in its business networks axis on the employees' performance is statistically significant, where the calculated $\mathrm{F}$ value was (30.498), with a significance level of ( $\mathrm{Sig} F=0.000)$ which is less than 0.05 . the correlation coefficient $(\mathrm{R}=0.473)$ indicates a positive relationship between the two factors, and the determination coefficient $\left(\mathrm{R}^{2}=0.478\right)$ indicates that $47.8 \%$ of the variance in employees' performance can be explained with the variance in the business networks. The table also shows that $(\beta=0.379)$ and this indicates the direct impact of the business networks on improving the employees' performance in the public goverance in Jerash, where T was (6.897) with a P-value of (0.001) which is less than $\alpha \leq 0.05$. Thus, we reject the second sub hypothesis and accept the alternative hypothesis that says there is a significant impact at level $\alpha \leq 0.05$ for the business networks on the employees' performance in the public governance in Jerash. 
Table 8. The results of the linear regression analysis for the impact of electronic management (information technology experts) on the employees' performance in the public governance in Jerash

\begin{tabular}{|c|c|c|c|c|c|c|c|c|}
\hline \multirow[b]{2}{*}{$\begin{array}{l}\text { Depended } \\
\text { variable }\end{array}$} & \multirow[b]{2}{*}{$\mathrm{R}$} & \multirow[b]{2}{*}{$\mathrm{R}^{2}$} & \multirow[b]{2}{*}{ F value } & \multirow[b]{2}{*}{ Sig } & \multicolumn{4}{|c|}{ Coefficient(a) } \\
\hline & & & & & $\begin{array}{l}\text { Item } \\
\text { Independent } \\
\text { variable }\end{array}$ & Beta & $\mathrm{T}$ & Sig.(P-value) \\
\hline $\begin{array}{l}\text { Employees' } \\
\text { performance }\end{array}$ & 0.488 & 0.469 & 40.498 & 0.000 & $\begin{array}{l}\text { technology } \\
\text { experts }\end{array}$ & 0.389 & 4.987 & 0.000 \\
\hline
\end{tabular}

The results in the previous table show that the impact of the independent variable (electronic management) in its information technology experts axis on the employees' performance is statistically significant, where the calculated $\mathrm{F}$ value was (40.498), with a significance level of ( $\mathrm{Sig} \mathrm{F}=0.000)$ which is less than 0.05. the correlation coefficient $(R=0.488)$ indicates a positive relationship between the two factors, and the determination coefficient $\left(R^{2}=0.469\right)$ indicates that $46.9 \%$ of the variance in employees' performance can be explained with the variance in the information technology experts. The table also shows that $(\beta=0.389)$ and this indicates the direct impact of the information technology experts on improving the employees' performance in the public governance in Jerash, where $\mathrm{T}$ was (4.987) with a P-value of (0.001) which is less than $\alpha \leq 0.05$. Thus, we reject the second sub hypothesis and accept the alternative hypothesis that says there is a significant impact at level $\alpha \leq 0.05$ for the information technology experts on the employees' performance in the public governance in Jerash.

\subsection{Discussion of the Results}

The results indicated that mean of the perspectives of the sample toward the electronic management in all its dimension was high, where the total average of all electronic management's dimension was (3.77) in the public governance in Jerash, where the business network guaranteed the first place with an average of (3.88), followed by hardware and software with an average of (3.77), then the databases with an average of (3.76), and finally the information technology experts with an average of (3.70). This shows the need for the government to provide the tools and infrastructure for the electronic management in the public governance in Jerash in order to change the procedures and the pattern of the management work from the handy way gradually into electronic way. The results of this study agreed with the results of the study by Al Abdullah (2006) the requirements for applying the electronic management in the Jordanian information systems', where he advised that the transformation to the electronic management is imperative forced by the international changes, where the idea of integration, participation, and applying the information became one of the determinants of the organization's success. The technological and scientific progress and the demand to increase the quality of the services implied the administrative development towards electronic management. The results also agreed with the study by (Abu Ashour and AlNemri, 2013) which studied the level of application of electronic management in Yarmouk University, and its results showed that the level of application from the perspective of the administrators was medium, and the university should provide the suitable infrastructure for the application of the electronic management by providing all the needed physical, technical, and human resources requirements to support using the applications of the electronic management in all the administrative works in the university.

Regarding the dependent variable (employees' performance), the average was high (3.81) for all the paragraphs, the employees' performance is considered the critical factor in completing the work, and one of the critical factors in the success of the public organizations where it is the most important episode in finishing the transactions of the citizens in the least time possible.

The results of the study showed that there is a statistically significant impact for the electronic management with all its dimension (hardware and software, databases, business networks, information technology experts) on the employees' performance, and this agrees with Rawash (2014) that the electronic management with all its dimension help the organization performing all administrative tasks like planning, control, and decision making, and it also helps removing some problems that inhibit the operations, like the problems concerning time, and security of information. Applying the electronic management increases the effectiveness and efficiency of the employees through participating in increasing the productivity of the workers, save time and effort and time, and reduce the cost. The results also agree with the study by (AlRasasi: 2016):) that the electronic management is one of the tools that 
help in the speed and flexibility of communication which facilitates making the right decision, and the electronic management should be updated with all its components and dimension to keep up with the quick changes in the business environment.

\section{Recommendations}

The analysis of this study can be used to provide some recommendations and instructions that were found in the field survey in the public goverance in Jerash regarding the role of the electronic management in activating the functionality of the employees to get more organizational performance and high quality outcomes, some of these recommendations and instructions:

1- The continuous follow up on the application of the concepts of the electronic management in the public, private, and services organizations in order to keep up with the challenges and developments in light of accessibility and globalization, and provide the needed services within a comprehensive model to satisfy the most number of people in the least time and cost.

2- The continuous check for information on the internal and external levels to discover the risks and deal with them in order to innovate in the response for the requirements and the demands of the customers which will create satisfaction for the administration and the customers.

3- Focus on the performance and behaviors of the employees to create the spirit of innovation and develop the electronic management by the recruitment of the right expertise, hold trainings, and stay updated in order to develop and expand toward a better future.

4- Provide an information bank for the identification, diagnosis, and the ability to predict the future challenges and developments and analyze them with an accurate and developed information systems.

5- Provide the fund for the electronic management to facilitate the procedures and organize the work to reach the speed in providing the needed services that go with the demands with the least cost.

\section{References}

Aboud, N. (2004). Electronic Management: Strategy, Tasks, and Problems. University Press, Ryadh, Saudi Arabia.

Abu Ashour, K., \& AlNemri, D. (2013). The Level of Applying the Electronic Management in Yarmouk University from the Perspective of the Administrators and Educational Board Members. Jordanian Magazine for Educational Sciences, 9(2), 199-220.

Abualoush, S., Bataineh.K., \& Aladwan A.S. (2017). Impact of Information Systems on Innovation (Product Innovation, Process Innovation) - Field Study on the Housing Bank in Jordon. International Journal of Business Administration, 8(1), 1-12.

Abualoush, S. (2015). The Role of Data Warehouse in Decreasing the Time of Decision Taking. Australian Journal of Basic and Applied Sciences, 9(5), 216-219.

$\mathrm{Al}$ Abdullah, Z. (2006). Electronic Government and Its Impact on the Efficiency of Operations. Unpublished Master thesis, Management and Economy Faculty, King AbdulAziz University, Ryadh, Saudi Arabia.

AlA'ani, M., \& Jawad, S. (2014). Electronic Management. Dar AlThaqafa press, Amman, Jordan.

AlAjez, I. (2011). The Role of Organizational Culture in Activating Applying the Electronic Management. Unpublished Master thesis, Islamic university, Gaza, Palestine.

AlAwamleh, N. (2003). The Quality of Electronic Management and Government in the Digital World; Survey Study. King Soud University Magazine, Administrative Sciences, 15(2), 267-283.

Al-bahussin.S.A., \& El-garaih, W. (2015). The Impact of Human Resource Management Practices Organisational Culture. Organisational Innovation and Knowledge Management on Organisational Performance in Large Saudi Organisations: Structural Equation Modeling With Conceptual Framework. International Journal of Business and Management, 8(22), 1-19.

AlBakhar, F. (2006). The Electronic Payment Tools, Electronic Business and Commerce. University Press, Alexandria.

Alead M., \& AlWadi, B. (2011). Knowledge and Electronic Management and It Modern Applications. Dar Alsafa, Jordan.

AlHadi, M. (2006). Electronic Government as a Tool for Development and Administrative Reform. Cybraiou Journal, AlSadat Academy for Administrative Sciences, 11, 234-265. 
AlHumaidi, N., AlSameraei, S., \& AlUbeid, A.R. (2009). Management Information Systems: Modern Approach $\left(2^{\text {nd }}\right.$ ed.). Amman, Wael press.

AlHusneiah, S. (2011). Management Information Systems: Information Management in the Digital Organizations Era.,3. AlWarraq press, Amman, Jordan.

AlHusseini, J., \& Dawood, S. (2006). The Technology of Computer Networks ( $2^{\text {nd }}$ ed.). Wael press, Amman.

AlKhawaldeh, R., \& AlHunaiti, M. (2008). The Impact of Using the Information Technology on the Administrative Innovation in the Jordanian Public Institutions Studies. Administrative Sciences, 35(2), 320-342.

AlMajdoub, T. (2005). Public Job and the Electronic Governmental Administrative Reform ( $1^{\text {st }}$ ed.). AlHalabi Legal Press, Halab.

AlRasasi.A. (2016). The Impact of Applying Electronic Management of Achieving Knowledge Management in the Jordanian Banks. Unpublished Master Thesis, Jadara University, Jordan.

AlSabbagh, \& Imad AbdulWahab. (1996). Computers in Business Administration: Systems Applications Administration (P.25). Dar Althaqafa press, Amman.

Alsamawi.A.A.T. (2014). The Effect of Training and Development (T\&D) on Employees'Performance in the Presence of Knowledge Management. The Ministry of Finance in Yemen: As ACase Study. Unpublished Master's Thesis, Middle east University, Jordan.

AlTaei, M. F. (2009). Introduction to Management Information System: Information Technology Management, 2, P.170. Wael press, Amman.

AlTaei, M. H. (2007). Strategic Planning for the Applications of Information Technology, Field Study on a Sample of the Jordanian Universities. Balqa applied university.

AlUteibi, M. (2007). The Impact of the Electronic Government on the Level of Employees' Performance: Field Study on King Abdulaziz University. Master Thesis, Public Administration Department, King AbdulAziz university, Ryadh, Saudi Arabia.

Awamleh.N. (2002). Electronic Government and the Future of the Public Administration/ Survey Study for the Public Sector in Qatar. Alkuwait Studies, 29(1), 40-65.

Badreddin. A. R. (2015). The Role of Information Systems Components in Improving the Administrative Performance in the West of Darfur. Magazine for Applied Science and Literature, 2, 25-45.

Bel Qasem. M. (2014). The Information System and Its Role in Decision Making. A Case Study, Algeria Communication Corporation- Alwadi. Unpublished Master Thesis, Qasdi Merbah University- Warqala, Algeria.

Darsana I. M. (2014). The Influence of Personality on Employee Performance through Organizational Citizenship Behavior. The International Journal of Management, 3(4), 1-8.

Elmasri, R. \& Shamkant.N. (2004). Fundamentals of Database Systems, Massachusetts: Pearson Education (4th ed., p.4).

Gungor, P. (2011). The Relationship between Reward Management System and Employee Performance with the Mediating Role of Motivation. Procedia Social and Behavioral Sciences, 24, 1510-1520. https://doi.org/10.1016/j.sbspro.2011.09.029

Iqbal.A., Ijaz.M., Latif.F., \& Mushtaq.H. (2015). Factors Affecting the Employee'S Performance: A Case Study of Banking Sector in Pakistan. European Journal of Business and Social Sciences, 4(8), 309-318.

Irtaimeh, H., Obeidat, A., M., abualous, S. H., \& Khaddam, A. (2016). Impact of Business Intelligence on Technical Creativity: A Case Study on AlHekma Pharmaceutical Company. European Scientific Journal, 12(28), 502-519. https://doi.org/10.19044/esj.2016.v12n28p502

Khammas, G. S. (2002). Information Technology and Its Impact on the Etechnical Setting in the Elibraries. Iraqi Magazine for Libraries And Information, 6(2), 146-158.

Laudon, K., \& Laudon, J. (2012). Management Information Systems (12 ${ }^{\text {th }}$ ed.). Pearson Prentice Hall, New Jersey.

Leonard, J. M., \& Valacich.S.J. (2006). Information systems Today ( $2^{\text {nd }}$ ed., p.399). Pearson Prentice Hall, New Jersey.

Maharani, V., Eka Afnan Troena, E. A. \& Noermijati. (2013). Organizational Citizenship Behavior Role in Mediating the Effect of Transformational Leadership, Job Satisfaction on Employee Performance: Studies in PT Bank Syariah Mandiri Malang East Java. International Journal of Business and Management, 8(17), 1-12. 
Njanja, W. L., R.. N. MainaL. K., \& Njagi.K. (2013). Effect of Reward on Employee Performance: A Case of Kenya Power and Lighting Company Ltd., Nakuru, Kenya. International Journal of Business and Management, 8(21), 41-49. https://doi.org/10.5539/ijbm.v8n21p41

Okoth.N.H. (2014). Effects of Reward Management on Employee Performance in Hotels in North Coast, Kenya, a Research Project Submitted in Partial Fulfillment of the Requirements for the Award of the Degree of Master of Business Administration (MBA). School of Business, University of Nairobi.

Qandeel, N. A. (2004). Electronic Commerce. Alshorouq, Cairo. Egypt .

Rawash, H.N. (2014). Electronic Management's Contribution to the Development of Managerial Functions. Academic Research International, 5(5), 213-225.

Razi, A. (2017). Impact of Teamwork, Esprit de corp, Team trust on Employee Performance in Royalindo Expoduta Jakarta Indonesia, International Journal Of Advancement In Engineering Technology. Management and Applied Science, 4(3), 1106-113.

Ruth, C. (2006). Does Information technology provides competitive Advantage and improves performance? An empirical Study of Trading Companies In Barazil. Baraxilan Business Review, 3(2), 175-199.

Shakkah, M. S., \& AlGamdi, S. A. (2016). An Investigation for Electronic Management Use in Educational Projects Management (A Case Study in AL Baha-KSA Area). American Journal of Economics and Business Administration, 8(1), 1- 8. https://doi.org/10.3844/ajebasp.2016.1.8

Silberschatz, A., Korth, H. F., \& Sudarshan, S. (2006). Database Systems Concepts (5th ed., p.3). MC Grow Hill, New York.

Sommer, D., \& James, R. (2004). Market Trends: Business Intelligence, worldwide, 2011-2014. p1. Gartner Group.

Sultana, A., Irum, S., Ahmed, K., \& Mehmood, N. (2012). Impact of Training on Employee Performance: A Study of Telecommunication Sector in Pakistan. Interdisciplinary Journal of Contemporary Research in Business, 4(6), 646-661.

Vratskikh, I., Masa'deh, R. M. T., Al-Lozi, M., \& Maqableh, M. (2016). The Impact of Emotional Intelligence on Job Performance via the Mediating Role of Job Satisfaction. International Journal of Business and Management, 11(2), 69-91. https://doi.org/10.5539/ijbm.v11n2p69

Whiteley, D. (2004). Introduction To Information Systems, Organizations, Applications, Technology And Design (P.222). Palgrave Macmillan, New York. https://doi.org/10.1007/978-1-137-10325-3_16

Yaseen, S. G. (2010). Electronic Management. Alyazouri Press, Amman, Jordan. 